\title{
SCIENCE COLLABORATION NETWORKS IN SOCIOLOGY AND THEIR GENERAL CHARACTERISTICS IN SERBIA ${ }^{1}$
}

Science collaboration networks occupy an important place in the analysis of social networks. There are several directions of concern in this kind of research: one attempts to explain the structure of science collaboration networks, the second one analyses the invisible scientific communities and the third one is dealing with the problems of different citation forms which function as a base from which many of the conclusions concerning these networks are being derived. However, the results of recent research in science collaboration networks indicate that there are a number of idiosyncratic characteristics of collaboration networks in sociology. In the first part of the paper the author analyzes the results of previous research of sociological social networks, published in scientific papers available in the following databases: JSTOR, ScienceDirect and SpringerLink. The authors then proceeds with the analysis of social networks of sociologists in Serbia and gives guidelines of the first research project dedicated to the analysis of social networks in Serbia.

Key words: science collaboration networks, Sociology, Serbia

\section{Introduction}

Science collaboration is a complex social phenomenon which is systematically studied since the second half of $20^{\text {th }}$ century. However, tribute for beginning of developement of the whole social networks theory should be given much earlier. Barabási (2006) reminds us of history of birth of the social networks idea and on event which happened in long gone 1736 in Sanct Petersburg, when Leonard Euler accidentally laid the groundwork of the graph theory, which is the basis of today's social networks analysis. Nevertheless, groundworks of the social networks theory were laid by two

1 This text came to life as a result of the work on the project entitled "The Significance of Participation in Social Networks for Adjustment to Eurointegrational Processes" (Значај партиципације у друштвеним мрежама за прилагођавање евроинтеграцијским процесима, бр. 179037), financially supported by the Ministry of Education and Science of the Republic of Serbia. 
Hungarian mathematicians, Paul Erdös and Alfred Rény. They in collaboration produced first scientific articles about how networks are being started. Popularity of Paul Erdős can be reflected through Erdös number which is used in measurement of our own distance, and good name, from this respected mathematician. Barabási (2002, 2006) explains that even the existence of Erdős number shows closely-knit network of scientific communities, in which the scientists are connected by creating works together. "Coautorship takes into consideration strong social connections and, due of that, the scientific network is the prototype of our social network." (Barabási, 2006: 56).

The questions which the authors are trying to give the answers to while explaining the collaboration networks in science are: how do we measure it, which factors influence the collaboration and which are the sources and effects of that collaboration. However, there are very few works which define what science collaboration is. The process of determining the boundaries of collaboration is prone to change. So, for instance, the boundary of collaboration between institutions, scientific fields, sectors, countries or even time-frames are understood in various ways, as Katz and Martin (1997) explained. They distinct five reasons because of which the number of research about scientific collaboration increased rapidly in the past three decades. The reasons are:

- escalating costs of fundamental research, so the resources must be pooled whether on regional, national or international level;

- significant decrease of travelling costs with simultaneous increase in informational technology and availability of information;

- scientific progress which largely depends on formal and informal interaction between scientists;

- greater need for specialisation and

- growing role of interdisciplinary research, which can be between science disciplines but also between different sectors (for example, between universities and industry) (Katz and Martin, 1997: 8-9).

The basic research unit of science collaboration is direct collaboration between two or more researchers, but it can also go on between research groups from one section, between sections of the same institution, between sectors, geographic regions and countries. After analysing the form of collaboration and additional costs incurred by it, Katz and Martin (1997) concluded that the term of "collaboration" is hard to define, because it is in great measure a thing of social conventions between scientists. That which by some would be considered as collaboration, others could define as loose grouping or collection of informal connections.

Description of collaboration by Katz and Martin is too wide and hard to operationalise. Their determining of the term of science collaboration networks asks for research on several levels: international, national, institutional and individual, and also 
for longitudinal and transversal aspect simultaneously with variety of network analysis. One of the few research programmes which meet this criteria is the work Abbasi et all (2011).

Researchers of the scientific networks more commonly opt for just one of its aspects and therefore narrow their operational definitions of science collaboration networks. A large number of authors base their analysis of science collaboration networks on concept of coautorship. Similar to Barabási, Newman (2001) identifies science network with coautorship, because he presumes that the authors who publish together are well-known to each other. In this kind of analysis, the actors (nods) are authors, and connections (links) between them are coauthored works. The connection exists if there is at least one coauthored work between two scientists. Sonnenwald (2007) is of opinion that scientific networks represent the interaction of scientists whose purpose is to exchange means and ends in order to accomplish a common goal.

The second way of analysing these networks is steered towards citation problem, which is more complex, and some would say more problematic than the analysis based on coauthorship. Škorić (2010) says that citation envelops many aspects: bibliographic pairing, co-citation, direct citation, symbolic citation, negative, diplomatic and auto citation. Small (1973) says that networks of co-citated works can be used for research of scientific specialties, while Kessler (1963) introduces the term bibliographic pairing. The results of these two analyses are different because the first one, which is dynamic, connects co-cited works, and the second one, which is static, connects source documents. Cole (1970) speaks about "ceremonial citation" as a demonstration in literature knowing and "diplomatic non-citation" as purposeful non-citation of authors from rival group etc. Based on analysis of citations from works from the field of Physics, Cole concludes that the visibility of scientific research is very stratified, because the quality work of scientists who work on most prestigious departments could be seen in the entire science system, while less influential research conducted at less influential departments remain mostly unknown. Separate problem for citation analysis is emergence of auto citation, which is widely spread in scientific works. Therefore Ruse (1979) considers solving this problem by exclusion of auto citation from analysis.

\section{Critique of Sociology}

During the 1990s, a significant number of American sociologists supported the opinion that Sociology in its organisational and intellectual sense does not have the results which are sought by them. Due to such circumstances among the sociologists, caused the editors of Sociological Forum to publish the special edition of their magazine in 1994 dedicated to the problem of „What's Wrong with Sociology?" Cole (1994a) explains that Sociology of that time 1) suffered from lack of theory which 
could be operationalised in research, 2) its theoretical development could not be measured against the development in nature sciences, 3 ) there was no cognitive consensus, 4) its methodology was in great discrepancy with research findings. Considering the organisational aspect, Cole states that some departments of Sociology were being closed, and some of them were about to close. The number of students was also dwindling down.

Cole (1994b) also emphasises that it is necessary to differentiate two kinds of knowledge in science: core knowledge and research frontier. The core knowledge consists of small group of theories and methods which are almost universally accepted as true and important from the relevant scientific circles, while the research frontier is consist of all newly produced knowledge, the largest parts of it being rejected as wrong. The core is connected with frontier by the mean of evaluation and only small percentage of new knowledge shifts from that frontier to the core. This process represents basic progress in all sciences.

Sociology, as Cole (1994b; also see Škorić, 2010) further explains, does not have core knowledge. The research frontier of Sociology expand but none of the knowledge from the frontier stand a chance of entering the core. There are two variables which influence the development of basic knowledge, and based on them, one can make a difference between natural and social sciences. They are: the degree in which the problem of study is variable, and the degree in which the choice of problem and the means for its solution are based on cognitive criteria. The differences between Physics and Sociology have more in common with the differences in the studied phenomena rather than with the characteristics of the people who study them. Sociologists cannot develop the general theory, because the choice of issues and offered solutions are under great influence of personal experiences and individual values. Similarly, Sociology did not develope the core knowledge similar to that in nature sciences, because of the problems in studying highly changeable occurrences, and also due to impossibility of separation of a sociologist as a scientist and a sociologist as a participant in occurrence which he studies. The first problem cannot be solved. Sociology would have to come to terms with developing middle or low-level general theories, while the second problem could be solved. Cole (1994b) states that there is no excuse for emphasizing non cognitive factors while doing sociological research and that the ways in which the problems are chosen must be changed.

Davis (1994) also explains that although many courses are well organised, many texts and books well written, they have little or no connection to each other. They can share methods, and even collections of data, but every work is dealing with the unique problem, with unique group of variables. It is very difficult to organise a list of main undersections of Sociology, without using using only the alphabet ordering criterion. In Sociology, there is no conflict about priorities, not because the sociologists are nice 
people, but because there cannot be found two sociologists who are studying the same problem. In Sociology there is no transversal incoherency, but also there is not much of serious longitudinal incoherency. Sociologists do not build cumulative knowledge. They do not deny or confirm or expand ideas, ideas just become boring so they move on to something new. In order for science to have reputation in intellectual and broader social reality, it must have its subject of study. However, sociologists share their subject of study with all of the social sciences and they have allowed others to practically banish them from important areas of social life. For Davis, the hardships do not stop there. Methods used in Sociology also represent the big problem, because a few of them came from Sociology. They are almost completely derived from other sciences. Further on, Davis states that most of the studies in lots of leading magazines are documented by, for example, logistical regression percentage columns, but sadly, many sociologists do not know how to interpret them. Davis (1994) concludes that Sociology sorely needs mid-level texts which deal with quantitative results, but in a qualitative way, and which emphasise that which we know, and not the way we got to that.

One of the problems separated for this occasion by Collins is application of statistics in sociological research. Collins (1994; also see Škorić, 2010) states that the progress of statistical methodology did not introduce high level of uniformity in a way in which sociologists conduct their research, and did not make a consensus or rapid discovery of essential questions. Using statistics in social research is part of theoretical manipulation of data, and not a method of producing new data, explains Collins further on. Sociological repertoire of technics of data gathering did not change much. Observation, questionnaires, experiments, historical analyses are similar to those a century before. In certain cases, the kind of data gathered with such methods changed (for example in network connections), together with data analysis methods. Collins states that one of the ways for Sociology to catch up with sciences with rapid discoveries is software development, such as social networks analyzing algorithms, or sociological theories simulation models. Therefore, the lack of social sciences is neither the lack of empirical research, nor the adhering to science epistemology, but it is genealogy of research technologies, which manipulation reliably produces new phenomena and fast movement of the research "front". In order for Sociology to become such science, Collins visualises the solution in new research technologies which are developed in microsociology and artificial intelligence.

\section{Sociological Collaboration Networks}

Among the first research which dealt with structure of collaboration networks in Sociology, we will single out the work of Small and Crane (1979), Cappell and Gutterbock (1992) and Ennis (1992). The research of collaboration networks of sociologists, which came after critique of Sociology stated above, had the goal to point to 
specifics of this science, besides revealing the structure of the network. Although lonely, the review and comparing of their results can explain to us what kind of collaboration is made by sociologists and which are the causes for forming these kinds of networks.

Moody (2004) in his research of the structure of collaboration networks in Sociology starts from the idea that although the connection between network and idea could be expected in small groups of scientists (in a sense that scientists who form collaboration networks share ideas, use similar techniques and influence one another in different ways), long-term trend in science work depends on wider pattern of social networks. Considering conclusions about critique of Sociology published 1994 in Sociological Forum 9(2) magazine, Moody explains that model of network influence shows that the exchange of ideas, research questions, methods and rules for evaluating implicit evidence between scientists, should generate consensus by structurally cohesive social connections, at least considering the problems and methods, if not individual statements about empirical life.

Moody (2004) further implies that theoretical understanding of differences inside the borders of disciplines demands understanding of its collaboration structure. Although sociology does not have a dominant theory (which exists in physics, for example), it has several autonomous research specialties. That which many have seen as a problem (a great dispersion of sociological disciplines, unintegrated research techniques, changes in financing of social sciences), for Moody, are the causes which created special research specialties, unique research techniques and standard ones for evaluation of evidence, which all implies a highly-grouped social network. Secondly, although many sociologists lack in great science names, "science stars" that attract more financing, students and collaborators, Moody agrees with Cole (1970) that they also produce an uneven distribution of participation in collaboration networks. Thirdly, the changes in research practice of sociologists together with passable theoretical limits can enable wide spectrum of collaboration which is not limited by disciplinary specialties. It is Moody's opinion that increase in sophisticated quantitative methods would lead to collaboration of sociologists from general and special disciplines. This process also shows far-reaching structural cohesion network.

While analysing the works published in Sociological Abstracts magazine in the period between 1963 and 1999, Moody (2004) concludes that coauthorship is becoming more frequent in Sociology, but it is not evenly distributed among sociological disciplines. It is present more often in areas in which quantitative analysis exists. As heterogeneity gives only limited information about social integration, the observations about division in Sociology based on the increasing number of specialties could be deceptive. The pattern of coauthorship shows a constantly growing cohesive core, 
which brings us to conclusion that although authors could specialise, their capabilities are successfully connected with others creating cohesive collaboration network.

However, Moody emphasises that network of coauthorship does not show the structure of the network. In order to discover that, he suggests the process of testing of three models: the preferential attachment model (in which the structure is based on "visible" authors), small-world model (where the scientists are grouped in loosely connected clusters) and structural cohesion model (which suggests all-encompassing connection within the large part of the network). Moody rejects the first model, and during the testing of the second one, he emphasises that findings suggest that collaboration network is not constituted of different, separated clusters, but from authors belonging to various specialties. In other words, connections appear between distant authors in the network. This finding is contrary to the premise about theoretical tearing of Sociology and little collaboration between sociologists, which is lamented by Davis (1994). Finally, Moody chooses the third model.

In one of the later researches (Kronegger et all, 2012) the authors combine the small-world model and preferential connection mechanism with the process of cumulative advantage (known as Metthew Effect), in order to model network dynamic. Kronegger et all (2012) checked three hypotheses: firstly, that coauthor science networks in all disciplines have a small-world structure; second, that the structure of coauthor networks is powered by preferential connection mechanism, and third, that organisational and institutional context influence the forming of coauthor science networks. They used the information of science publications published from 1991 till 2005 and generated network according to coauthored publications. As basic indicators of small-world network they chose the average distance between scientists in network and clustering coefficients. Average distance between sociologists in Slovenia was 3.00 (for Physics it was 3.97, Biotechnology it was 4.36 and Mathematics 3.91). Comparing that to results of the previous research (Moody, 2004) where the clustering coefficient was between 0.2 and 0.3 , the authors explain that the high value of this coefficient in Slovenia, as one of the small countries, is probably the consequence of its network border. Besides, we are talking about small networks "they are bounded by national borders and organizational structure of science on the national level" (Kronegger et all, 2012: 640). High values of the coefficients can be observed as a consequence of transition and point to scientific work on a local level, so the authors conclude it is probably about the forming of intermediary network.

Apart from the scale-free distribution of degrees, Kronegger et all (2012) used one more indicator of preferential connection structure, and that was the stability of network based on the number of its components. They explain that the removal of scientists with the highest visibility would have a dramatic influence on the rest of the network, if it is the preferential connection network. Their results show that the most 
stable network structure is that of the physicists, then mathematicians, biotechnologists and, lastly, sociologists. Authors conclude that in Slovenia the coauthor network of mathematicians and biotechnologists is maintained and that very process is based on a very small number of significant authors, which is not the case with Physics and Sociology.

While the preferential mechanisms focus exclusively on the forming of coauthorship connections, one should bear in mind the changes in collaboration of scientists. This means that scientists who collaborated at one time, do not necessarily need to continue to do so later. For dynamic network modelling Kronegger et all (2012) used networks measured in three time waves. While doing that, they found out 13 changes (the forming or terminating of coauthorship work) in physicists' network from the first to the second measurement, 21 change in sociologists' network, 4.8 changes in biotechnologists' and 2.4 changes in mathematicians' network. In the following transition, the average number of changes for single units in network slightly grows in mathematicians and biotechnologists, while in physicists and sociologists there is almost no change at all.

Kronegger et all (2012) also found some mutual characteristics of networks in all studied sciences:

1) the forming of the new connections has a negative prefix, which is a duly expected consequence of "costs" in time, effort and resources, which every new connection has for every researcher. The creation of new connections, if the "costs" of this kind are considered, can lead to the breakdown of already established connections.

2) There is a tendency of participants to form connections in such a way that they create a triangle. In all four disciplines, scientists are inclined to form new coauthorship connections with coauthors of their coauthors, which is irrefutable confirmation of high grouping inside network borders and a clear indicator of small-world network structures.

3) The influence coming from the same research group was confirmed as a predictor of the tendency to form the new coauthor connection, which points to the significant influence of formal institutional structures on the scientific cooperation.

4) The connection was found among the biotechnologists between the researchers of different age groups (e.g. mentors/tutors and students), while it has not been the case with psysicists, mathematitians and sociologists.

The authors of this reasearch have confirmed the first hypothesis, while the evidence for the second one are of mixed nature. Certain principles have been confirmed in Mathematics and Sociology but not in Physics or Biotechnology. The third hypoth- 
esis has been confirmed in different ways and has mainly been dependant on the organisations of local institutions and publishing cultures.

Even though Kronegger and his associates used the same methodology as Moody did, we have seen that the results of their research point out different network structures which are realised by the sociologists. There are many reasons due to which Moody chose the structural cohesion model and the authors of the other research used the small-world model. The first ought to stress the wider socio-political and economic context within the framework where the scientific community is developing, because the number of contacts realised by the scientists depends on financial support of the Ministries. The second reason is the very size of the scientific community observed in the national frameworks. In this context, the more dominating scientific community will create more visible scientific names, around which certain groups of scientists will be formed. As the first and the second research confirm that the cooperation between sociological disciplines exist (as they also confirm that they are in constant increase), in the first case, the cooperation indeed will point to the model chosen by Moody, whereas it might lead to the seperate groups between which there are very few connections in the case of smaller scientific communities.

\section{Possibilities and limitations of research of the scientific collaboration networks in Serbia}

The first thesis on science collaboration networks on the territory of Serbia was published by Mimica and Vuletic (1998). These authors deal with the analysis of quoting the classics of Marx, Weber and Durkheim by the authors who have been publishing in Sociologija, one of the leading sociological magazines in Serbia. However, after this text, the analysis of social networks has been tranfered into the sphere of research of Serbian pscychologists (see Šipka, 1995, 2005a), whereas in Sociology the complete loss of interest is noted for this particular topic.

Even though the Serbian scientific community cannot be praised for its influential works in the sphere of Scientometrics, its international appraisal was gained by its own citation index - SCIndex (Šipka, 2005b, 2010). Serbian citation index was created by the scientists of the Evaluation Centre in Education and Science (www.ceon.rs) according to the ISI citation indexes, but with the extended purpose and data model. Created as such, SCIndex has many other roles: "evaluation tools, instruments for quality control of works and magazines and, lastly, the platforms for promotion and dissemination of domestic results of scientific thesis." (Šipka, 2010: 284)

Apart from SCIndex and fewer scientific works from this sphere of interest, sociologists in Serbia do not show greater interest for the analysis of social networks. Sociology is being studied at three universities in Serbia: Belgrade, Novi Sad and Niš, how- 
ever, there is not one subject which is dedicated to the theory and analysis of social networks in their study programmes.

Nevertheless, in 2011, the first scientific project dedicated to social networks started its realisation phase, supported by the Ministry of Education and Science of the Republic of Serbia. The project entitled "The Significance of Participation in Social Networks for Adjusting to Eurointegrational Processes" has been started with the aim to promote theory and analysis of social networks to Serbian sociological and broader scientific audience.

In that sense, it is quite reasonable to start research with the analysis of published authors' and coauthors' works in three sociological magazines: Sociološki pregled, Sociologija and Teme, in the period between the year 2000 and 2010. The proportion of author works in total number of published texts is $89.1 \%$, whereas the proportion of coauthor works is merely $10.9 \%$. We have analysed coauthors' works according to the criterion of belonging to the same or different scientific/educational institution. The conclusion is that the participation of coauthors who are employed in the same institutions is twice as higher than the participation of the authors who cooperate with the colleagues from the other scientific institutions (see table 1).

Table 1: Frequency of authors' and coauthors' works in magazines Sociološki pregled, Sociologija and Teme for the period 2000-2010

\begin{tabular}{|c|c|c|c|c|c|c|c|}
\hline \multirow[t]{3}{*}{ Magazine } & \multicolumn{2}{|c|}{ Author works } & \multicolumn{4}{|c|}{ Coauthor works } & \multirow[t]{3}{*}{ TOTAL } \\
\hline & & & \multicolumn{2}{|c|}{$\begin{array}{l}\text { From the same } \\
\text { institution }\end{array}$} & \multicolumn{2}{|c|}{$\begin{array}{l}\text { From different } \\
\text { institutions }\end{array}$} & \\
\hline & Freq. & Prop. & Freq. & Prop. & Freq. & Prop. & \\
\hline Sociološki pregled & 210 & 27.1 & 24 & 3.1 & 11 & 1.3 & 245 \\
\hline Sociologija & 201 & 25.9 & 22 & 2.8 & 9 & 1.2 & 232 \\
\hline Teme & 280 & 36.1 & 9 & 1.2 & 10 & 1.3 & 299 \\
\hline TOTAL & 691 & 89.1 & 55 & 7.1 & 30 & 3.8 & 776 \\
\hline
\end{tabular}

Based on this insight, we can conclude that the scientific networks of coauthors' works of sociologists in Serbia are not quite developed. The problem posed here is of an ambivalent nature: the first one is professional, while the second one can be traced in broader social context, in which one scientific community is being developed. The question why the Serbian sociologists do not cooperate during the writing of scientific works cannot be answered easily. In Serbian Sociology there are no distinguished scientists who tend to gather younger associates, who could deal with a certain scien- 
tific issue. One type of possible explanations comes from the previous sociological scientific projects, which gathered the Serbian sociologists. According to our own judgement, those were not entirely team projects, since the themes have been of quite a general nature, never stressing the realistic scientific problems. Problems related to the project are mostly chosen based on such general notion which could enable the project work of the associates who could tackle various issues, without the obligation to step out of their own profession. This means that they could dedicate themselves to handling a mutual problem. The second type of an explanation is more general and overcomes the boundaries of Serbia. As Moody (2004: 222) concludes: out of 100\% of the works published in Sociological Abstract, in the period between 1963 and 1999, only $33.2 \%$ belong to the coauthors' works. Considering the fact that the issue is about comparing scientific communities of various sizes, the samples of such a distribution of authors' and coauthors' works are quite different. In smaller scientific communities sometimes a situation may occur when there is one or merely several scientists who deal with a specific problem, therefore, there is a possibility of team work and cooperation between the sociologists who are in general and those who are in specific disciplines for which Moody claims it will be developed in the future.

The second type of problem emerges from social circumstances in which one scientific community is developing. During the 1990s, Serbia found itself in a very difficult political and economic situation caused by the distruction of the former SFRY, by wars in its midst and sanctions brought upon. The isolation of the country brought about the tough downfall of the entire economic potential of the country. Among all else, it produced minimal investment in science, as well as hard and minimal international cooperation. Therefore, it does not come as a surprise that the cooperation of the Serbian sociologists at the beginning of the $21^{\text {st }}$ century was three times smaller than the cooperation of the sociologists portrayed in Moody's research. However, during the last several years, the number of Serbian scientists who join the international projects is on the increase, hence, they are enabling far better scientific cooperation and, therefore, the production of more coauthors' works, which should reflect on the increase of the number of such thesis in the domain of Sociology.

\section{LITERATURE}

Abbasi, A., H. Liaquat, U. Shahadat and K. J. R. Rasmussen (2011). Evolutionary dynamics of scientific collaboration networks: melti-levels and cross-time analysis. Scientimetrics 89: 687710 .

Barabási L.-A. et al. (2002). Evolution of the social network of scientific collaborations. Physica A 311: 590-614. 
Barabási L.-A. (2006). U mreži. Zašto je sve povezano i kako misliti mrežno u znanosti, poslovanju i svakodnevnom životu. Zagreb: Naklada Jesenski i Turk.

Cappell, L. C., T. M. Guterbock (1992). Visible Colleges: The Social and Conceptual Structure of Sociology Specialties. American Sociological Review 57(2): 266-273.

Cole, R. J. (1970). Patterns of intellectual influence in scientific research. Sociology of Education 43(4): 377-403.

Cole, S. (1994a). Introduction: What's Wrong with Sociology? Sociological Forum 9(2): 129-131.

Cole, S. (1994b). Why Sociology Doesn`t Make Progress like the Natural Sciences. Sociological Forum 9(2): 133-154.

Collins, R. (1994). Why the Social Sciences Won`t Become High-Consensus, Rapid Discovery Science. Sociological Forum 9(2): 157-177.

Davis, A. J. (1994). What`s Wrong with Sociology? Sociological Forum 9(2): 179-197.

Ennis, G. J. (1992). The Social Organization of Sociological Knowledge: Modeling the Intersection of Specialties. American Sociological Review 57(2): 259-265.

Katz, J. S., B. R. Martin (1997). What is research collaboration? Research Policy 26: 1-18.

Kessler, M. M. (1963). Bibliographic coupling between scientific papers. American Documentation 14(1): 10-25.

Kronegger, L., F. Mali, A. Ferligoj, P. Doreian (2012). Collaboration structures in Slovenian scientific communities. Scientometrics 90: 631-647.

Mimica, M. A., V. Vuletić (1998). Gde se dade treći klasik? Analiza citiranosti Marksovih, Veberovih I Dirkemovih radova u časopisu Sociologija 1959-1996. Sociologija 40(1): 79-94.

Moody, J. (2004). The Structure of a Social Science Collaboration Network: Disciplinary Cohezion from 1963 to 1999. American Sociological Review 69(2): 213: 238.

Newman, J. E. M. (2001). The Structure of Scientific Collaboration Networks. Proceedings of the National Academy of Sciences of the United States of America 98(2): 404-409.

Ruse, M. (1979). Review of Social Stratification in Science. Social indicators Research 6(4): 495502.

Small, H. G. (1973). Co-citation in the scientific literature: A new measure of the relationship between two documents. Journal of the American Society for Information Science 24(4): 265269.

Small, H., D. G. Crane (1979). Specialties and Disciplines in Science and Social Science: An Examination of Their Structure Using Citation Indexes. Scientometrics 1(5-6): 445-461

Sonnenwald, H. D. (2007). Scientific collaboration: A synthesis of challenges and strategies. Annual Review of Information Science and Technology 41: 643-681.

Šipka, P. (1995). Citatna analiza jugoslovenske psihološke periodike 1981-1990: odnosi među pokazateljima individualne citiranosti. Psihologija 28(1-2): 195-206.

Šipka, P. (2005a). Društvene nauke u Srbiji, s Momirovićem i bez njega: jedan bibliometrijski portret. Psihologija 38(3): 345-360.

Šipka, P. (2005b). The Serbian Citation Index: Context and Content. Proceedings of the $10^{\text {th }}$ Conference of the International Society for Scientometrics and Informetrics. Stockholm, pp. 710-711.

Šipka, P. (2010). Vruća retorika i hladna realnost: prilog proveri. Sociološki pregled 44(2): 283-307.

Škorić, M. (2010). Sociologija nauke. Mertonovski i konstruktivistički program. Novi Sad: Izdavačka knjižarnica Zorana Stojanovića. 
Жолт Лазар

Сажее̄̄ак

Валентина Соколовска

Универзитет у Новом Саду

Филозофски факултет

\section{САРАДНИЧКЕ МРЕЖЕ У СОЦИОЛОГИЈИ И ЊИХОВЕ ОСНОВНЕ КАРАКТЕРИСТИКЕ У СРБИЈИ}

Сарадничке мреже у науци заузимају значајно местио у анализи социјалних мрежса. Постиоји неколико йраваца у којима се крећу ова истираживања: йрви је објашњење сйрукіиуре сарадничке мреже, друіи је усмерен ка анализи невидљивих научних

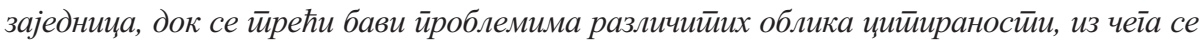
изводе значајни закључци о научним мрежама. Резулйайи досадашьих исйраживана сарадничких мрежса у науции йакође указују и на неке моїућносиии социолоїије као науке. У йрвом делу рада ауйори се баве анализом резулйайа исиираживана друшиивених мрежка у сочиолойји, објављених у научним радовима досииуйним у базама JSTOR,

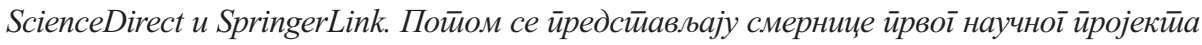
йосвећеної социјалним мрежсама у Србији, са йосебним найласком на йроблеме юихове анализе.

Кључне речи: сарадничке мреже у науци, сочиолоїја, Србија 